\title{
Biological aspects of the predatory mite, Amblyseius fallacies Garman (Phytoseiidae) feeding on thrips nymphs under laboratory condition.
}

\author{
Abdel-Karim, H. S. and Abd EL- Wareth, H. M. \\ Plant Protection Research Institute - Agricultural Research Center.
}

\begin{abstract}
Predaceous mites play an important role in the biological control of phytophagous mites and insect pests such as thrips and whitefly. Biological parameters of Amblyseius fallacies Garman were tested under two degree of temperature 20 and $30^{\circ} \mathrm{C}$ and R.H. $70 \pm 5 \%$ feeding on Thrips tabaci at Fac. Agric., Fayoum Univ., Egypt from March till June. The results indicated that the mean of immature periods at $20^{\circ} \mathrm{C}$ for eggs, larvae, protonymphs and deutonymphs, reached (2.64, 1.14, 1.86 and 2.79 days) and $(2.46,1.07,1.93$ and 3.21 days) for females and males, respectively. At $30^{\circ} \mathrm{C}$ the mean of these periods for female reached (2.64, $1.00,1.64$ and 3.21 days), while for males reached (2.50, 1.07, 1.29 and 3.43 days), respectively. The adult longevity period averaged at $20^{\circ} \mathrm{C}$ were $10.29 \& 9.29$ days, while at $30^{\circ} \mathrm{C}$ averaged were $8.14 \& 6.86$ days for female and males, respectively. Through the oviposition period which averaged between 6.43 and 4.71 days the mean of eggs deposited per female reached to 8.86 and 9.29 eggs at $20^{\circ} \mathrm{C}$ and $30^{\circ} \mathrm{C}$, respectively. The total mean of food consumption for immature stages ( protonymphs and deutonymphs) reached to 3.00 and 2.43 preys at $20^{\circ} \mathrm{C}$, while reached to 3.43 and 2.71 preys at $30^{\circ} \mathrm{C}$ for females and males, respectively. The adult stage consumed from 19.89 to 9.14 preys at $20^{\circ} \mathrm{C}$ and 23.58 to 10.57 preys at $30^{\circ} \mathrm{C}$ for females and males, respectively.
\end{abstract}

Key words: Predaceous mites, Amblyseius fallacies and biological aspects.

\section{INTRODUCTION}

The Phytoseiidae are the most common plant inhabiting predatory mites. They have been considered to play an important role in the natural control of some phytophagous mites and insects. Several phytoseiid species have been commercially produced for the control of pest mites, thrips and whiteflies, Moraes and McMurtry (1981). Many species of Phytoseiidae are predators of mite pests; they are thus of huge interest in biological control programs. This family is widespread all over the world and includes three sub-families and more than 2,000 valid species Kostiainen \& Hoy (1996) and McMurtry \& Croft (1997). Variation in prey selection behavior, resulting in quantitative and / or qualitative differences in food intake, may results in differences in reproductive success. If this variation is genetically determined, natural selection is expected to favor thus genotypes that maximize their contribution to future generations. It is there fore expected that phytoseiid mites do not feed indiscriminately but prefer certain food types over others Van Lenteren (1986).

Biological control of thrips with predatory mite releasing began in European sweet pepper crops infested with the onion thrips, Thrips tabaci. Following several years of research, commercial use of Amblyseius cucumeris , A. barkeri (mckenziei) and A. fallacies Garman was begun in 1985 in Holland with releases on about 25\% of the Dutch pepper acreage under glass (De Klerk and Ramakers 1986).Natural enemies, such as predaceous mites Amblyseius fallacies Garman (Phytoseiidae) 
caused reduction of more pests (especially piercing and sucking pests). Predaceous mites play an important role in the biological control of phytophagous mites and some insect pests ( Sengonca and Drescher, 2001). A. fallacies feeds on mites on berry and fruit crops, as well as a supplement to $P$. persimilis in greenhouse situations. A. fallacies can also survive on lower pest densities and feed on a variety of food sources such as two-spotted mites, European red mite and pollen. A. fallacies is pear-shaped and about the same size as it's prey and hairless. It is reddish in color when feeding on the European red mite, gold when feeding on the two-spotted spider mite in strawberries and blotchy green when feeding on the two-spotted spider mite in cane berries. Predator-prey interactions between phytoseiids and tetranychids in Japan revealed that the native predators Amblyseius longispinosus and A. eharai and the introduced predator Phytoseiulus persimilis were potential biological control agents of tetranychid mites reported by Mori et al., (1990). Thrips palmi was an important pest of several crops, especially vegetables. The predatory mite A. cucumeris was successfully used in the control of various thrips species reported by, Cuellar et al., (2002). The predatory mites P. persimilis and A. cucumeris in commercial greenhouses for augmentative biological control of thrips used by Opit et al., (2005).

The present work aims to study some biological aspects of A. fallacies and investigate the effect of temperature and relative humidity under laboratory conditions.

\section{MATERIALS AND METHODS}

The biological aspects of predaceous phytoseiid mite $A$. fallacies were obtained during 2010 under laboratory conditions at 20 and $30^{\circ} \mathrm{C}$ and R.H.70 $\pm 5 \%$ feeding on Thrips tabaci at Fac. Agric., Fayoum Univ., Egypt from March till June.

A. fallacies was found in Fayoum Governorate on several plants (Family: Cucurbitaceae), associated with phytophagous mites, mainly Tetranychus urticae and insect pests such as Bemisia tabaci and Thrips tabaci. T. urticae was offered daily to this predator as a main source of food on fresh bean leaves placed on wet cotton pad in plastic tray. Water was added daily to maintain suitable moisture. The stock culture was maintained at $25 \pm 2{ }^{\circ} \mathrm{C}$ and R.H. $70 \pm 5 \%$. The adult females of $A$. fallacies were collected from the field of vegetable crops (such as, Bean; Potato; Eggplant; Pepper and Cucumber) and transferred to the laboratory then supplied with prey larvae as food. Every newly predator egg was put singly on plastic rings $1 \mathrm{~cm}$ in $5 \mathrm{~cm}$ Petri dish with agar medium, kept under constant temperature degree $\left(20\right.$ and $\left.30^{\circ} \mathrm{C}\right)$. After hatching the predator was supplied with prey as food. Disks were checked daily during the entire developmental periods to determine the duration of developmental stages and number of consumed prey El-Laithy and Fouly (1992) and El-Laithy (1998).

Source of prey: Leaves infested by T. tabaci were collected with much enough number of prey from vegetable plants (Bean; Potato; Eggplant; Pepper and Cucumber) throughout the study period of predator. Nymphs were obtained from the culture and offered to the predator. The means of results were subject to statistical analysis using T-test of significances. The Duncan's procedures and the means were compared at $0.05 \%$ of probability by Duncan (1955).

\section{RESULTS AND DISCUSSION}

\section{A- The development stages are presented in table (1) and show that:}




\section{1-Incubation period:}

The incubation period of $A$. fallacies at $20^{\circ} \mathrm{C}$ ranged between 2-3.5 days with a mean of $2.64 \pm 0.26$ for male and female and between 2-3 days with a mean of $2.5 \pm 0.15$ at $30^{\circ} \mathrm{C}$ for male. Statistical analysis of the data revealed the presence of non-significant differences between the mean duration of egg stage for male and female at 20 and $30^{\circ} \mathrm{C}$, respectively. These results are in general agreement with those obtained by Kain and Nyrop (1995), Riudavets 1995, and Sabelis and van Rijn (1997) who found that $A$. fallacies mite lays its eggs on the undersides of leaves near the top of the plant. The average is 2 eggs laid per female per day.

Table 1: Mean duration of $A$. fallacies immature stages at $20 \& 30^{\circ} \mathrm{C}$ and $70 \%$ R.H.

\begin{tabular}{|c|c|c|c|c|}
\hline \multirow{2}{*}{$\begin{array}{c}\text { Immature } \\
\text { periods }\end{array}$} & \multicolumn{2}{|c|}{$20^{\circ} \mathrm{C}$} & \multicolumn{2}{c|}{$30^{\circ} \mathrm{C}$} \\
\cline { 2 - 5 } & Males & Female & Males & Female \\
\hline \multirow{2}{*}{ Eggs } & $2-3.5$ & $2-3.5$ & $2-3$ & $2-3$ \\
& $2.64^{\mathrm{a}} \pm 0.26$ & $2.64^{\mathrm{a}} \pm 0.26$ & $2.50^{\mathrm{a}} \pm 0.15$ & $2.64^{\mathrm{a}} \pm 0.15$ \\
\hline \multirow{2}{*}{ Larvae } & $0.5-1.5$ & $1-2$ & $0.5-1.5$ & $0.5-1.5$ \\
& $1.07^{\mathrm{a}} \pm 0.17$ & $1.14^{\mathrm{b}} \pm 0.24$ & $1.07 \mathrm{a} \pm 0.17$ & $1.00^{\mathrm{a}} \pm 0.15$ \\
\hline \multirow{2}{*}{ Protonymph } & $1.5-2.5$ & $1.5-2.5$ & $1-1.5$ & $1-2.5$ \\
& $1.39 \mathrm{~b}^{\mathrm{a}} \pm 0.17$ & $1.86^{\mathrm{a}} \pm 0.14$ & $1.29 \mathrm{~b} \pm 0.10$ & $1.64^{\mathrm{a}} \pm 0.21$ \\
\hline \multirow{2}{*}{ Deutonymph } & $2.5-4.5$ & $2.5-4.5$ & $2.5-4.5$ & $2.5-4.5$ \\
& $3.07^{\mathrm{a}} \pm 0.25$ & $2.79^{\mathrm{b}} \pm 0.20$ & $3.43^{\mathrm{a}} \pm 0.30$ & $3.21^{\mathrm{b}} \pm 0.31$ \\
\hline
\end{tabular}

Duncan's Multiple Rang Test $\mathrm{P}<0.05$

\section{2-Larval stage:}

The larval duration period of female was ranged between 1-2 days and 0.5-1.5 days with a mean of $1.14 \pm 0.24$ and $1.00 \pm 0.15$ days at 20 and $30^{\circ} \mathrm{C}$, respectively. While, the larval duration period of male was ranged between 0.5-1.5 days and 0.51.5 days with a mean of $1.07 \pm 0.17$ and $1.07 \pm 0.17$ days, respectively. Statistical analysis of the data revealed the presence of significant differences between the mean duration of larval stage for male and female at $20{ }^{\circ} \mathrm{C}$, respectively. While, at $30^{\circ} \mathrm{C}$ non-significant were observed.

\section{3- Protonymphal stage:}

In female, the protonympal period ranged between 1.5-2.5 days and 1-2.5 days at $20^{\circ} \mathrm{C}$ and $30^{\circ} \mathrm{C}$, with a mean of $1.86 \pm 0.14$ and $1.64 \pm 0.21$, respectively. While those for male ranged between 1.5-2.5 days and 1-1.5 days with a mean of $1.39 \pm 0.17$ and $1.29 \pm 0.10$ days at $20^{\circ} \mathrm{C}$ and $30^{\circ} \mathrm{C}$, respectively.

Statistical analysis of the data revealed the presence of non-significant differences between the mean duration of protonymphal stage for male and female at 20 and $30^{\circ} \mathrm{C}$, respectively.

\section{4- Deutonymphal stage:}

The deutonympal time in female and males was ranged between 2.5-4.5 days with a mean of $2.79 \pm 0.20$ days in females and $3.07 \pm 0.25$ days in males at $20^{\circ} \mathrm{C}$. While, at $30^{\circ} \mathrm{C}$ the deutonympal time in females and males, ranged between 2.5-4.5 days with a mean of $3.21 \pm 0.31$ days in females and $3.43 \pm 0.30$ days in males. The period of total immature varied with sex and temperature. It ranged for females between 7-11 days and 6.5-11.5 days with a mean of $8.50 \pm 0.65$ and $8.36 \pm 0.63$ days at $20^{\circ} \mathrm{Cand} 30^{\circ} \mathrm{C}$, respectively. While the period of immature for males, ranged between 6.5-11.5 and 6-10.5 days with a mean of $8.71 \pm 0.75$ and $8.21 \pm 0.60$ days, respectively. Statistical analysis of the data revealed the presence of non-significant differences between the mean duration of deutonymphal stage for male and female at 20 and $30^{\circ} \mathrm{C}$, respectively. 
These results are in general agreement with those obtained by Van Houten et al,. (1995) and Zhang Hui-yuan et al.,(2010) who stated that A. fallacies could complete its development period and lay eggs with one generation time of $9.54 \mathrm{~d}$ at $(25 \pm 1)^{\circ} \mathrm{C}$. Riudavets (1995) and Sabelis and van Rijn (1997) found that at $\left(25^{\circ} \mathrm{C}\right), 6.2$ days are required to complete the life cycle for $A$. fallacies, also they found the $A$. cucumeris completes its life cycle in $11.1,8.7$, and 6.3 days at $\left(20,25\right.$ and $\left.30^{\circ} \mathrm{C}\right)$. The lower threshold for larval development is $\left(7.7^{\circ} \mathrm{C}\right)$.

\section{B- The adult female longevity are presented in table (2) and show that: 1- Pre-oviposition period:}

The preovipositin period ranged between 2-3 and 1-3 days with a mean of $2.43 \pm 0.20$ and $1.86 \pm 0.34$ days at 20 and $30^{\circ} \mathrm{C}$, respectively. Statistical analysis of the data revealed that significant effect on the pre-oviposition period for female at 20 and $30^{\circ} \mathrm{C}$, respectively.

Table 2: Some biological aspects of A. fallacies feeding on T. tabaci nymphs at $20 \& 30^{\circ} \mathrm{C}$ and $70 \%$ R.H.

\begin{tabular}{|c|c|c|c|c|}
\hline \multirow{2}{*}{ Biological aspects } & \multicolumn{4}{|c|}{ Period in days \pm SD } \\
\cline { 2 - 5 } & \multicolumn{2}{|c|}{$20^{\circ} \mathrm{C}$} & \multicolumn{2}{c|}{$30^{\circ} \mathrm{C}$} \\
\cline { 2 - 5 } & Range & Average & Range & Average \\
\hline Preovipostion & $2-3$ & $2.43^{\mathrm{a}} \pm 0.20$ & $1-3$ & $1.86^{\mathrm{b}} \pm 0.34$ \\
\hline Oviposition & $4-9$ & $6.43^{\mathrm{a}} \pm 0.65$ & $3-6$ & $4.71^{\mathrm{b}} \pm 0.42$ \\
\hline Postoviposition & $1-3$ & $1.71^{\mathrm{a}} \pm 0.29$ & $1-2$ & $1.43^{\mathrm{a}} \pm 0.20$ \\
\hline Longevity & $7-15$ & $10.29^{\mathrm{a}} \pm 1.02$ & $5-11$ & $8.14^{\mathrm{b}} \pm 0.86$ \\
\hline Life span & $15-21$ & $17.71^{\mathrm{a}} \pm 0.75$ & $13-17$ & $14.57^{\mathrm{b}} \pm 0.57$ \\
\hline No. of eggs/female & $5-13$ & $8.86^{\mathrm{a}} \pm 1.06$ & $4-17$ & $9.29^{\mathrm{a}} \pm 1.74$ \\
\hline
\end{tabular}

Duncan's Multiple Rang Test $\mathrm{P}<0.05$

\section{1- Oviposition period:}

The oviposition period ranged between 4-9 days and 3-6 days with a mean of $6.43 \pm 0.65$ and $4.71 \pm 0.42$ days at 20 and $30^{\circ} \mathrm{C}$, respectively. Statistical analysis of the data revealed that significant effect on the duration of oviposition period for female at 20 and $30^{\circ} \mathrm{C}$, respectively.

\section{2- Post-oviposition period:}

The post-oviposition period ranged between 1-3 days and 1-2 days with a mean of $1.71 \pm 0.29$ and $1.43 \pm 0.20$ days at 20 and $30^{\circ} \mathrm{C}$, respectively. Statistical analysis of the data revealed that non-significant effect on the post-oviposition period for female at 20 and $30^{\circ} \mathrm{C}$, respectively. In females, the adult longevity ranged between $7-15$ days and 5-11 days with a mean of $10.29 \pm 1.02$ and $8.14 \pm 0.86$ days at 20 and $30^{\circ} \mathrm{C}$, respectively. Statistical analysis of the data revealed that significant effect on the longevity period for female at 20 and $30^{\circ} \mathrm{C}$, respectively. While, the adult male longevity ranged between 8-12 days and 5-9 days with a mean of $9.29 \pm 0.52$ and $6.86 \pm 0.60$ days at 20 and $30^{\circ} \mathrm{C}$, respectively table (3).

Table 3: Longevity and life span of $A$. fallacies males (immature and adults) which feeding on $T$. tabaci nymphs at $20 \& 30^{\circ} \mathrm{C}$ and $70 \%$ R.H.

\begin{tabular}{|c|c|c|c|c|c|}
\hline \multicolumn{2}{|c|}{ Biological aspects } & \multicolumn{2}{c|}{$20^{\circ} \mathrm{C}$} & \multicolumn{2}{c|}{$30^{\circ} \mathrm{C}$} \\
\cline { 3 - 6 } \multicolumn{2}{|c|}{$\begin{array}{c}\text { Period in } \\
\text { days }\end{array}$} & Range & Average & Range & Average \\
\cline { 2 - 5 } & Life span & $13-18$ & $9.29^{\mathrm{a}} \pm 0.52$ & $5-9$ & $6.86^{\mathrm{a}} \pm 0.60$ \\
\hline \multirow{2}{*}{$\begin{array}{l}\text { No. of prey } \\
\text { devoured }\end{array}$} & Longevity & $6-13$ & $9.14^{\mathrm{a}} \pm 0.63$ & $9-14$ & $11.29^{\mathrm{b}} \pm 0.17$ \\
\cline { 2 - 6 } \pm 0.33 & $8-14$ & $10.57^{\mathrm{a}} \pm 0.18$ \\
\hline
\end{tabular}

Duncan's Multiple Rang Test $\mathrm{P}<0.05$ 
Statistical analysis of the data revealed that non-significant effect on the longevity period for male at 20 and $30^{\circ} \mathrm{C}$, respectively. These results are in agreement with those obtained by Kain and Nyrop (1995), Helle and Sabelis (1985).

\section{C- Fecundity:}

Laboratory observations reported that, the adult female of $A$. fallacies deposited eggs ranged between 5-13 days and 4-17 eggs per female with an average of $8.86 \pm 1.06$ and $9.29 \pm 1.74$ eggs at 20 and $30^{\circ} \mathrm{C}$, respectively table (2). Statistical analysis of the data revealed that non-significant effect on the fecundity for female at 20 and $30^{\circ} \mathrm{C}$, respectively.

Different results were obtained by Zhang Hui-yuan et al., (2010) who stated that the average amount of eggs laid by female A.cucumeris was 36.70. El-Laithy (1998) found that Agistemus exsertus had the highest fecundity rate of 66.6 eggs/ female, followed by Amblyseius swirskii 44.4 and P. finitimus 23.5 eggs / female.

\section{D- Life span:}

In females, this duration of life span ranged between 15-21 days and 13-17 days with an average $17.71 \pm 0.75$ and $14.57 \pm 0.57$ days at 20 and $30^{\circ} \mathrm{C}$, respectively table (2). Statistical analysis of the data revealed that significant effect on the life span for female at 20 and $30^{\circ} \mathrm{C}$, respectively.

While, the corresponding value for males lasted from 13-18 days and 9-14 days with a mean of $15.14 \pm 0.63$ and $11.29 \pm 0.17$ days table (3). Statistical analysis of the data revealed that significant effect on the life span for male at 20 and $30^{\circ} \mathrm{C}$, respectively. These results are in agreement with those obtained by Kain and Nyrop (1995), Helle and Sabelis (1985). El-Laithy (1998) found that the predatory mites successfully fed on Eriophyes olivi . The developmental time of the predaceous mites averaged 10.5, 5.7 and 7.9 days, for Agistemus exsertus, Amblyseius swirskii and P. finitimus, respectively. Different results were obtained by Zhang Hui-yuan et al., (2010) who stated that life span was (38.52 d) of female. Reis et al.(2007) studied the life history of predatory mite A. hericolus using Brevipalpus phoenicis as prey. The adult female had a longevity of 38 days. The intrinsic rate of population increase was 0.15 and the mean generation time was 25.3 days.

\section{E- Predation potential:}

\section{1- Larvae:}

2- The observations reported that, the larval stage of both predator sexes could not feed on thrips nymphs table (4).

Table 4: Mean consumption of immature stages of A. fallacies upon feeding on T. tabaci nymphs at 20 $\& 30^{\circ} \mathrm{C}$ and $70 \%$ R.H.

\begin{tabular}{|c|c|c|c|c|}
\hline \multirow{2}{*}{ Biological aspects } & \multicolumn{2}{|c|}{$20^{\circ} \mathrm{C}$} & \multicolumn{2}{c|}{$30^{\circ} \mathrm{C}$} \\
\hline Immature stage & Male & Female & Males & Female \\
\hline Larvae & - & - & - & \\
\hline \multirow{2}{*}{ Protonymph } & $1-2$ & $1-2$ & $1-2$ & $1-2$ \\
& $1.29^{\mathrm{a}}$ & $1.29^{\mathrm{a}}$ & $1.43^{\mathrm{a}}$ & $1.57^{\mathrm{a}}$ \\
\hline Deutonymph & $1-3$ & $1-4$ & $1-3$ & $1-4$ \\
& $1.86^{\mathrm{b}}$ & $2.29^{\mathrm{a}}$ & $2.00^{\mathrm{b}}$ & $2.57^{\mathrm{a}}$ \\
\hline \multirow{2}{*}{ Total } & $2-3$ & $2-4$ & $2-4$ & $3-5$ \\
& $2.43^{\mathrm{b}}$ & $3.00^{\mathrm{a}}$ & $2.71^{\mathrm{b}}$ & $3.43^{\mathrm{a}}$ \\
\hline
\end{tabular}

Duncan's Multiple Rang Test $\mathrm{P}<0.05$

\section{1- Protonymphs:}

In female, the protonymph consumed $1-2$ and 1-2 prey with a mean of 1.29 and 1.57 prey at $20^{\circ} \mathrm{C}$ and $30^{\circ} \mathrm{C}$, respectively. While the protonymph of male 
consumed 1-2 and 1-2 prey with a mean of 1.29 and 1.43 prey table (4). Statistical analysis of the data revealed that non-significant differences between the means of protonymphs for male and female at 20 and $30^{\circ} \mathrm{C}$, respectively.

\section{2- Deutonymphs:}

The number of T. tabaci nymphs consumed by female was 1-4 and 1- 4 prey with a mean of 2.29 and 2.57 prey at $20^{\circ} \mathrm{C}$ and $30^{\circ} \mathrm{C}$, respectively. But, the number of T. tabaci nymphs consumed by male was 1-3 and 1-3 prey with a mean of 1.86 and 2.00 prey, respectively. The total consumption of female immature ranged 2-4 and 3-5 prey with average 3.00 and 3.43 prey. While for immature male consumed 2-3 and 24 prey with average 2.43 and 2.71 prey at 20 and $30^{\circ} \mathrm{C}$, respectively table (4). Statistical analysis of the data revealed the presence of significant differences between the means of deutonymphs for male and female at 20 and $30^{\circ} \mathrm{C}$, respectively. These results are in agreement with those obtained by Reis et al.(2007) who found that predation and ovipostion of $A$. herbicolus increased with increasing prey density.

\section{3- Adult:}

As shown in table (5) the Pre-oviposition, Oviposition and Post-oviposition periods of female the predator consumed at $20^{\circ} \mathrm{C}(2-7),(6-15)$ and (2-5) prey with average $4.43,12.23$ and 3.23 prey, respectively. While at $30^{\circ} \mathrm{C}$ these periods ranged (2-9), (8-19) and (3-6) prey with average 5.86, 13.43 and 4.29 prey, respectively table (5). These results are in agreement with those obtained by Kain and Nyrop (1995), Helle and Sabelis (1985). Riudavets (1995) and Sabelis \& van Rijn (1997) found that, a pair of mites Amblyseius cucumeris eat five $1^{\text {st }}$ larvae of WFT each day on average, but older life stages are immune to attack because of their larger size and more effective defensive behaviors.

The total consumption of adult female the mite consumed 10-27 and 13-34 prey with average 19.89 and 23.58 prey, and during life span consumption ranged between $14-28$ and $18-33$ preys with average 21.43 and 26.86 preys at 20 and $30^{\circ} \mathrm{C}$, respectively table (5). While adult male consumed from 6-13 to 8-14 preys with average 9.14 and 10.57 preys, and life span consumption ranged between 9-14 and 11-16 preys with average 11.57 and 13.29 preys at 20 and $30^{\circ} \mathrm{C}$, respectively table (3). Similar results were obtained by Kain and Nyrop (1995) Helle and Sabelis (1985). Riudavets (1995) and Sabelis and van Rijn 1997) observed and recorded that female mites (Amblyseius barkeri) live 30 days and over this time consume about 89 first instar thrips larvae. This predator aggregates on high density patches of WFT larvae, where it feeds on young larvae and lays its eggs. Statistical analysis of the data revealed the presence of significant differences between the means of Preoviposiotion, Oviposition, Post-oviposition, longevity and life span for female at 20 and $30^{\circ} \mathrm{C}$.

Table 5: Food consumption of A. fallacies females (immature and adults) upon feeding on T. tabaci nymphs at $20 \& 30^{\circ} \mathrm{C}$ and $70 \%$ R.H.

\begin{tabular}{|c|c|c|c|c|}
\hline \multirow{2}{*}{ Biological aspects } & \multicolumn{4}{|c|}{ No. of prey devoured } \\
\cline { 2 - 5 } & \multicolumn{3}{|c|}{$20^{\circ} \mathrm{C}$} & \multicolumn{2}{c|}{$30^{\circ} \mathrm{C}$} \\
\cline { 2 - 5 } & Range & Average & Range & Average \\
\hline Preovipostion & $2-7$ & $4.43^{\mathrm{b}}$ & $2-9$ & $5.86^{\mathrm{a}}$ \\
\hline Oviposition & $6-15$ & $12.23^{\mathrm{b}}$ & $8-19$ & $13.43^{\mathrm{a}}$ \\
\hline Postoviposition & $2-5$ & $3.23^{\mathrm{b}}$ & $3-6$ & $4.29^{\mathrm{a}}$ \\
\hline Longevity & $10-27$ & $19.89^{\mathrm{b}}$ & $13-34$ & $23.58^{\mathrm{a}}$ \\
\hline Life span & $14-28$ & $21.43^{\mathrm{b}}$ & $18-33$ & $26.86^{\mathrm{a}}$ \\
\hline
\end{tabular}

Duncan's Multiple Rang Test $\mathrm{P}<0.05$ 


\section{REFERENCES}

Cuellar, M. E.; A. C., Bellotti and E. L., Melo (2002). Aspects of the biology and rate of consumption of Amblyseius cucumeris and Typhlodromus aripa (Acari: Phytoseiidate) on he host Thrips palmi Karny (Thysanoptera:Thripidae). Revista Colombiana de Entomologia, 28 (1): 1-7.

De Klerk, M. L. and P. M. J. Ramakers (1986). Monitoring population densities of the phytoseiid predator Amblyseius cucumeris and its prey after large scale introductions to control Thrips tabaci on sweet pepper. Mededelingen van de Faculteit Landbouwwetenschappen Rijksuniversiteit Gent 51 (3a): 1045-1048.

Duncan, D. B. (1955): Multiple rang and multiple F test. Biometrics., 11:1-42.

El-Laithy, A. Y. M. (1998): Laboratory studies on growth parameters of three predatory mites associated with eriophyid mites in olive nurseries. Zeitschrift fur Pflanzenkrankheiten und Pflanzenschutz, 105 (1): 78-83.

El-Laithy, A. Y. M. and A. H., Fouly (1992): Life table parameters of the two phytoseiid predators Amblyseius scutalis (Athias- Henriot) and A. swirskii (A.-H.) ( Acari: Phytoseiidae) in Egypt. J. Appl. Ent.,113: 8-12.

Helle, W. and M.W., Sabelis (Eds.) (1985) Spider mites: Their Biology, Natural Enemies and Control. Vol. 1B. Elsevier, Amsterdam. 458 pp.

Kain, D. and J. M., Nyrop (1995). Predatory Mites. Insect Identification Fact Sheet No. 23. Cooperative Extension, Cornell University, Ithaca, NY.

Kostiainen, T.S. and M.A., Hoy (1996). The Phytoseiidae as biological control agents of pest mites and insects. A bibliography. Monograph 17, University of Florida, Agricultural Experiment Station, $355 \mathrm{pp}$.

McMurtry, J.A. and B.A., Croft (1997). Life-styles of Phytoseiidae mites and their roles in biological control. Annual Review of Entomology, 42: 291-321. Moraes, G.J. and J.A., McMurtry (1981). Biology of Amblyseius citrifolius (Acarina: Phytoseiidae). Hilgardia, 49: 1-29.

Mori, H.; Y., Saito and H. Nakao (1990). Use of predatory mites for controlling spider mites (Acarina: Tetranychidae) in Japan. FFTC-NARC International Seminar on 'the use of parasitoids and predators to control agricultural pests Tukuba Science City, Ibarakiken, 305 Japan, 22pp.

Opit, G. P.; J. R. Nechols; D. C. Margolies and K. A. Williams (2005). Survival, horizontal distribution and economics of releasing predatory mites (Acari: Phytoseiidate) using mechanical blowers. Biological Control, 33 (3): 344-351.

Reis,P. R.; A.V., Teodoro; N. M. Pedro and E. A., Silva (2007): Life history of Amblyseius herbicolus ( Chant) (Acari: Phytoseiidae) on coffee plants. Neotropical Entomology, 36 (2): 282-287.

Riudavets, J. (1995). Predators of Frankliniella occidentalis (Perg.) and Thrips tabaci Lind.: a review, pp. 43-87. In Loomans, A. J. M., J. C. van Lenteren, M. G. Tommasini, S. Maini, and J. Riudavets (eds.). Biological Control of Thrips Pests. Wageningen Agricultural University Papers 95-1, printed by Veenman Drukkers, Wageningen, The Netherlands.

Sabelis, M.W. and P.C.J. van Rijn, (1997). Predation by insects and mites, pp. 259354 In Lewis, T. (ed.) Thrips as Crop Pests. CAB International, United Kingdom.

Sengonca, C. and K. Drescher (2001): Laboratory studies on the suitability of Thrips tabaci Lindeman (Thsanoptera: Thripidae) as prey for the development, longevity, reproduction and predation of four predatory mite species of the 
genus Amblyseius (Acari: Phtoseiidae) Zeitschrift fur Pflanzenkrankheiten und Phanzenschutz, 108 (1): 66-76.

Van Houten, Y. M., P. C. J. van Rijn, L. K. Tanigoshi, and P. van Stratum. (1995). Preselection of predatory mites to improve year-round biological control of western flower thrips in greenhouse crops. Entomologia Experimentalis et Applicata, 74: 225-234.

Van Lenteren, J.C. (1986). Evaluation, mass production, quality control and release of entomophagous insects. In: J. M. Franz (Editor). Biological Plant and Health Protection. Gustav Fischer, Stuttgart, pp. 31-56.

Zhang Hui-yuan, M. A.; T. L. Ming DONG; X. Y., Zhang Kun and F. L. Wang (2010). Biological control efficiency of Amblyseius cucumeris (Oudemans) on Panonychus ulmi (Koch). Chinese Journal of Applied Ecology, 1: 151-160.

\section{ARABIC SUMMARY}

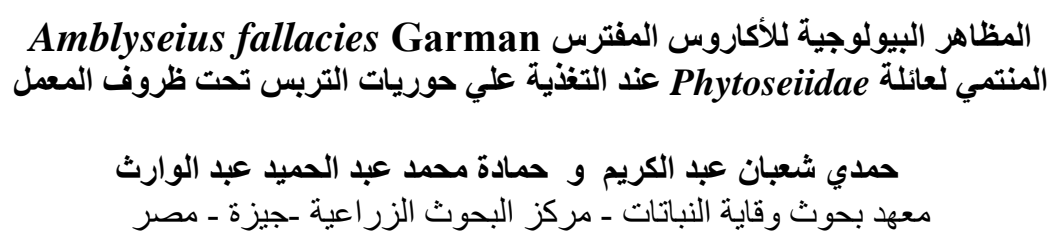

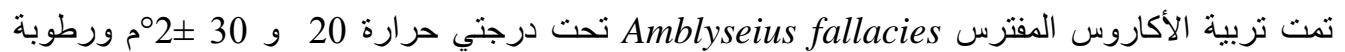

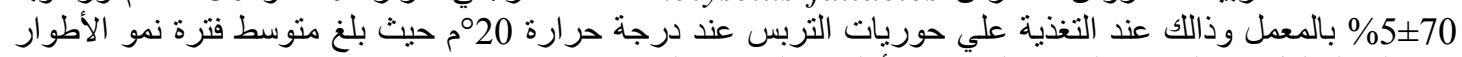

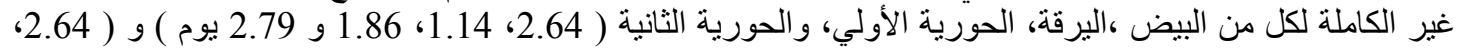

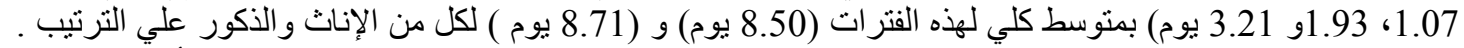

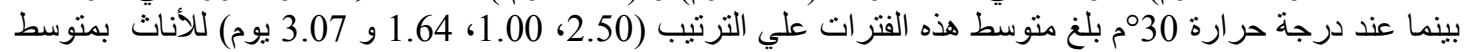

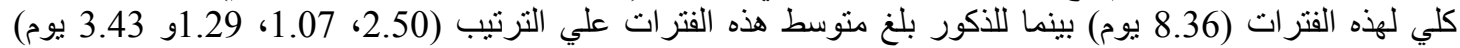

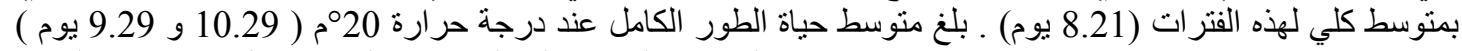

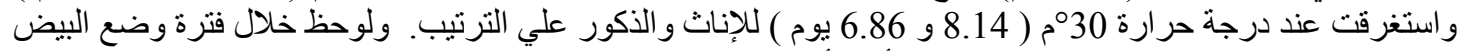

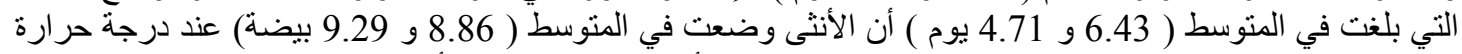

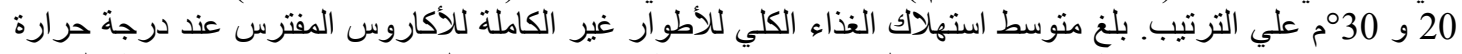

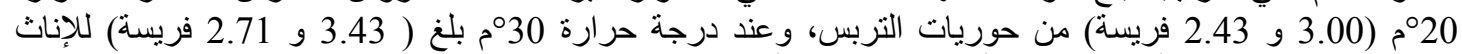
و الذكور علي الترتيب. وأثتتث الدراسة أن الطور الكامل أستهلك في الكنوسط (193.

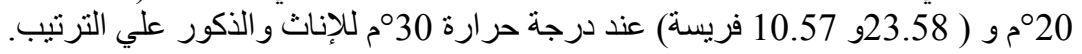

